\title{
Oral keratinocytes support non-replicative infection and transfer of harbored HIV-I to permissive cells
}

\author{
Anjalee Vacharaksa1,2, Anil C Asrani 1,2, Kristin H Gebhard 1,2, \\ Claudine E Fasching2, Rodrigo A Giacaman1,2, Edward N Janoff ${ }^{2,3}$, \\ Karen F Ross ${ }^{1,2}$ and Mark C Herzberg*1,2
}

\begin{abstract}
Address: ${ }^{1}$ Department of Diagnostic and Biological Sciences, School of Dentistry, University of Minnesota, Minneapolis, MN 55455, USA, ${ }^{2}$ Mucosal and Vaccine Research Center, Minneapolis VA Medical Center, Minneapolis, MN 55417, USA and ${ }^{3}$ Division of Infectious Diseases, Colorado Center for AIDS Research, and the Mucosal and Vaccine Research Program Colorado, University of Colorado Denver, and the Denver Veterans Affairs Medical Center, Denver, CO 80220, USA

Email: Anjalee Vacharaksa - tang0160@umn.edu; Anil C Asrani - asran003@umn.edu; Kristin H Gebhard - kristingebhard@mac.com; Claudine E Fasching - Claudine.Fasching@va.gov; Rodrigo A Giacaman - giac0015@umn.edu; Edward N Janoff - Edward.Janoff@ucdenver.edu; Karen F Ross - rossx007@umn.edu; Mark C Herzberg* - mcherzb@umn.edu
\end{abstract}

* Corresponding author

Published: 17 July 2008

Retrovirology 2008, 5:66 doi:10.1186/1742-4690-5-66

This article is available from: http://www.retrovirology.com/content/5/I/66

(c) 2008 Vacharaksa et al; licensee BioMed Central Ltd.

This is an Open Access article distributed under the terms of the Creative Commons Attribution License (http://creativecommons.org/licenses/by/2.0), which permits unrestricted use, distribution, and reproduction in any medium, provided the original work is properly cited.

\section{Abstract}

Background: Oral keratinocytes on the mucosal surface are frequently exposed to HIV-I through contact with infected sexual partners or nursing mothers. To determine the plausibility that oral keratinocytes are primary targets of HIV-I, we tested the hypothesis that HIV-I infects oral keratinocytes in a restricted manner.

Results: To study the fate of HIV-I, immortalized oral keratinocytes (OKF6/TERT-2; TERT-2 cells) were characterized for the fate of HIV-specific RNA and DNA. At $6 \mathrm{~h}$ post inoculation with X4 or R5-tropic HIV-I, HIV-I gag RNA was detected maximally within TERT-2 cells. Reverse transcriptase activity in TERT-2 cells was confirmed by VSV-G-mediated infection with HIV-NL4$3 \Delta$ env-EGFP. AZT inhibited EGFP expression in a dose-dependent manner, suggesting that viral replication can be supported if receptors are bypassed. Within $3 \mathrm{~h}$ post inoculation, integrated HIVI DNA was detected in TERT-2 cell nuclei and persisted after subculture. Multiply spliced and unspliced HIV-I mRNAs were not detectable up to $72 \mathrm{~h}$ post inoculation, suggesting that HIV replication may abort and that infection is non-productive. Within $48 \mathrm{~h}$ post inoculation, however, virus harbored by CD4 negative TERT-2 cells trans infected co-cultured peripheral blood mononuclear cells (PBMCs) or MOLT4 cells (CD4+ CCR5+) by direct cell-to-cell transfer or by releasing low levels of infectious virions. Primary tonsil epithelial cells also trans infected HIV-I to permissive cells in a donor-specific manner.

Conclusion: Oral keratinocytes appear, therefore, to support stable non-replicative integration, while harboring and transmitting infectious X4- or R5-tropic HIV-I to permissive cells for up to 48 h. 


\section{Introduction}

During oral-sexual contacts and breast feeding, oral keratinocytes of the stratified squamous epithelium represent the most abundant cell type exposed to infectious HIV-1 [1-5]. Since HIV-1 gag RNA is detected in cytokeratin-positive cells of mucosal biopsies [6] and shedding buccal cells [7], HIV-1 could infect and persist in oral keratinocytes during primary infection or secondary to systemic dissemination. HIV-1 that is harbored in keratinocytes could be transferred to proximal immature dendritic (Langerhans) cells of the mucosal epithelium. These Langerhans cells present HIV-1 to permissive CD4+ T lymphocytes. Alternatively, permissive lymphoid cells could access virus at inter-epithelial spaces where HIV-1 particles have been visualized by electron microscopy [7].

In infant $[8,9]$ and adult primates [10], cell-free simian immunodeficiency virus (SIV) infects intact oral mucosa within one day after non-traumatic exposure and viral RNA is detected in the proximal epithelium. About four days later, signs of SIV infection appear in the gut, followed by viremia and simian AIDS. Hence, the pathogenesis of SIV-infection in primates is consistent with the possibility that clinical exposures of HIV-1 to the oral and oropharyngeal mucosa result in primary infections of the keratinocytes in the squamous epithelium. Primary human infections from an oral epithelial focus, therefore, could result in systemic dissemination of HIV-1.

Oral keratinocytes use an atypical mechanism to facilitate entry of HIV-1. In permissive cells, which express CD4, HIV-1 efficiently enters cells using gp 120-mediated membrane fusion [11-13]. Since oral keratinocytes do not express CD4 [14], HIV-1 entry into keratinocytes is expected to be less efficient than other permissive cells. Galactosylceramide (GalCer) [15] and heparin sulfate proteoglycans (HSPGs) $[16,17]$ have been suggested to be alternate receptors for HIV-1 on CD4-negative cells including keratinocytes, enabling HIV-1 to enter host cells in an envelope-independent manner [18]. After internalization, HIV-1 may be mobilized intracellularly by selective and rapid transcellular vesicular trafficking [19].

Based on in vitro studies, it is unclear if HIV-1 replicates in oral keratinocytes or if the cells harbor and transfer infectious particles (trans infect) to permissive cells such as peripheral blood mononuclear cells [20-22]. Suggestive of viral integration, HIV-1 ${ }^{\mathrm{LTR} / \mathrm{gag}}$ DNA has been isolated from primary gingival keratinocytes [20], but HIV-1 LTR/gag PCR primers could have amplified unintegrated linear HIV-1 DNA. HIV-1 propagated in permissive producer cells is contaminated by integrated human HIV-1 DNA sequences [23]. These sequence contaminants are potentially mistaken for new integration events when detected by PCR. To remove contaminating DNA, HIV-1 has been treated with DNase before infection of keratinocytes, but the efficacy of this approach was not reported [24]. Other studies of oral keratinocytes [20-22] have not reported expression of integrated HIV DNA or two-LTR circles [25].

To determine the fate of HIV-1 in oral keratinocytes, we investigated key life cycle events reported in permissive cells $[26,27]$, including viral entry, integration, and the expression of HIV-specific genes. To eliminate interpersonal variability that can confound studies of primary cells in culture, we studied immortalized OKF6/TERT-2 (TERT-2) cells as a genetically and phenotypically consistent oral keratinocyte [28] target for HIV-1 infection. Originally isolated from the floor of a human mouth, TERT-2 cells show a normal phenotype and an extended replicative life span [28]. We hypothesized that HIV could integrate and replicate in TERT-2 oral keratinocytes, produce sufficient HIV-1 to infect neighboring permissive cells, and that key steps in the life cycle are demonstrable. Since receptive transmission by an oral route occurs infrequently [29], HIV-1 infection and viral production were expected to be of low abundance in TERT-2 cells. To show convincingly that HIV-1 integrates into the genome of keratinocytes, albeit at low levels, highly sensitive nested PCR was utilized. To eliminate contaminating integrated human HIV-1 DNA sequences derived from producer cells, genomic DNA was isolated directly from the nuclei of HIV-1 inoculated TERT- 2 cells and the fate of HIV-specific RNA was followed over time.

\section{Results \\ Oral keratinocytes capture and transfer HIV-I to infect peripheral blood mononuclear cells}

Primary tonsil epithelial (TE) cells from six donors were compared for the ability to transfer (trans infect) HIV-1 to peripheral blood mononuclear cells (PBMCs) in vitro (Fig. 1A). After incubation with HIV-1 (IIIb or BaL) for $6 \mathrm{~h}$, TE cells from some donors (nos. 144, 195, 196, and 1101) appeared to capture and transfer the lab-adapted HIV strains; exceptions included TE cells from donor tissues 193 and 233 (Fig. 1A). To avoid the subject-to-subject variability seen in primary TE cell cultures, we evaluated TERT-2 cells for further study of capture, infection, replication and transfer of HIV-1 to permissive cells.

TERT-2 cells appeared to transfer both HIV- 1 strains to PBMCs (Fig. 1B), with average effectiveness when compared to the TE cells from different donors (Fig. 1A). Performed in parallel with TERT-2 cells, trans infection by TE cells (tissue no. 233) was consistent with the previous experiment and similar to non-permissive mouse fibroblasts (NIH 3T3) (Fig. 1B). At similar levels to TERT-2 cells, several other keratinocyte cell lines, including TR146 [30] and KB [31], also trans infected HIV-1 IIIb and BaL to permissive cells (data not shown). 

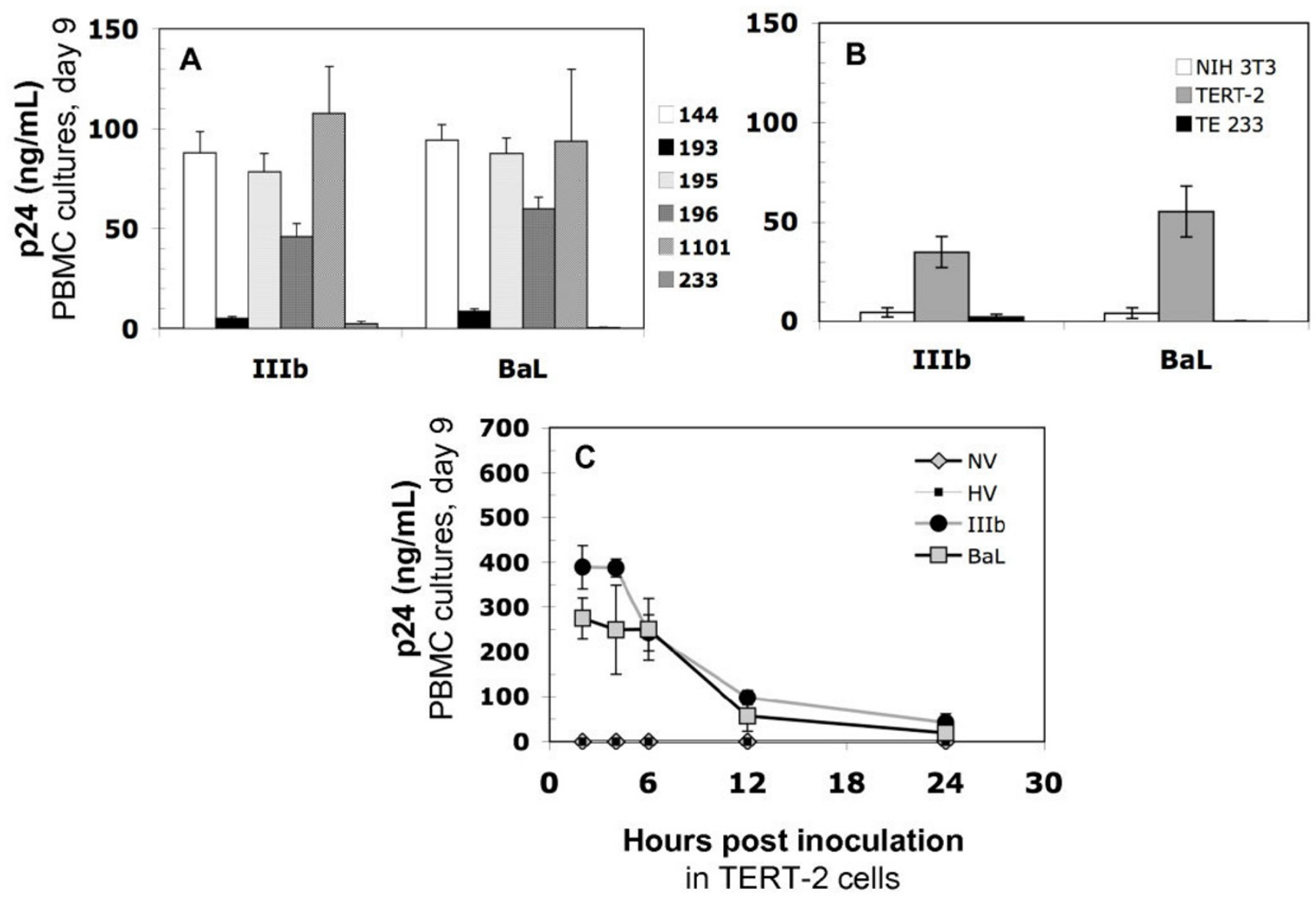

Figure I

Oral keratinocytes trans infect HIV-I to permissive PBMCs. TERT-2 or TE monolayers were inoculated and incubated for $6 \mathrm{~h}$ with lab-adapted HIV-I, IIlb or BaL. Tonsils were obtained from six donors (tissues I44, I93, I95, I96, II0I, and 223). Cells from each donor were propagated separately and TE cells were cultured as described in Materials and Methods. After incubation, cells were trypsinized, washed to remove non-internalized particles, and then co-cultured with PHA-activated PBMCs $\left(2 \times 10^{5}\right.$ cells $)$ in PBMC growth media. To estimate HIV-I trans infection from keratinocytes, PBMCs supernatants were collected on day 9 post inoculation and $244^{\mathrm{gag}}$ expression was estimated using ELISA. (A) TE cells from each donor differentially trans infect HIV-I to PBMCs. (B) TERT-2 and TE 223 cells were tested side-by-side in the same experiments to compare HIV uptake and transfer. Mouse fibroblast cells (NIH 3T3) were included as a negative control. (C) To investigate the rate of HIV-I trans infection over time, TERT-2 cells were trypsinized and washed to remove extracellular HIV-I at indicated times post inoculation. TERT-2 cells from each time point were then co-cultured with PBMCs and p24gag production was analyzed. TERT2 cells incubated with media only (no virus; NV) or heat-inactivated HIV-I BaL (HV) were included as negative controls. Data in panel $A$ represent the mean \pm standard deviation of triplicate determinations in one experiment since the availability of primary tonsil cells from each donor was limited. Data in panel $B$ and $C$ are reported as the mean \pm standard deviation from three independent experiments each performed in triplicate.

To determine the time course of uptake and transfer, HIV1 was incubated with TERT-2 cells (MOI 0.01), trypsinized to remove extracellular virus, and co-cultured with PBMCs at indicated times for up to $24 \mathrm{~h}$. After incubation with HIV-1 for up to 6 h, TERT-2 cell internalized HIV-1 appeared to be maximally transferable to PBMCs. Trans infection of internalized HIV-1 from TERT-2 cells decreased to the limits of detection by $24 \mathrm{~h}$ post inoculation (Fig. 1C).

\section{Putative HIV receptor expression on TERT-2 oral keratinocytes and TE primary cells}

Since oral keratinocytes are negative for CD4 [21], we analyzed TERT-2 cells for alternative HIV receptors and coreceptors by flow cytometry (Table 1 ) and immunofluorescence staining (data not shown). In preliminary experiments, candidate molecules of interest were cleaved from TERT-2 cells when harvested using trypsin (data not shown). Consequently, TERT-2 cells were harvested with- 
Table I: Putative HIV receptor expression on oral keratinocytes

\begin{tabular}{|c|c|c|c|}
\hline Receptor & Function & $\begin{array}{c}\text { TE } \\
(\text { Mean } \pm \text { SD })^{\mathrm{a}}\end{array}$ & $\begin{array}{c}\text { TERT-2 } \\
(\text { Mean } \pm \text { SD })^{\mathrm{b}}\end{array}$ \\
\hline CDI04 ( $\beta 4$ integrin) & $\begin{array}{l}\text { transmembrane protein expressed predominantly in } \\
\text { epithelial cells [32] }\end{array}$ & $80 \pm 11$ & $83 \pm 4$ \\
\hline HSPGs & HIV gp I 20 binding [70] & $13 \pm 7$ & $91 \pm 20$ \\
\hline GalCer & HIV gp 20 binding [7I] & $4 \pm 0.1$ & $<1$ \\
\hline CD4 & HIV gp I 20 binding [72] & $<1.0$ & $<1$ \\
\hline CXCR4 & X4-tropic chemokine co-receptor [73] & $<1.0$ & $3.5 \pm 2$ \\
\hline CCR5 & R5-tropic chemokine co-receptor [73] & $<1.0$ & $<1$ \\
\hline $\begin{array}{l}\text { CD3, CDI Ia/LFA-I, CD32, CD64, CD89, DC-SIGN, } \\
\text { Macrophage Mannose Receptor }\end{array}$ & & $<1.0$ & Not tested \\
\hline Human fibroblast & & $4 \pm 4$ & Not tested \\
\hline
\end{tabular}

a Mean \pm SD of four independent experiments (I experiment from tissue no. 164 and 193, and 2 experiments from tissue no. 196)

b Mean \pm SD of three independent experiments

out trypsin for flow cytometry analysis. TERT-2 cells were negative for CD4 as expected (Table 1) and $80 \%$ of the cells were positive for CD104, a $\beta 4$-integrin chain generally expressed by epithelial cells [32] (Table 1). TERT-2 cells were also positive for HSPGs $(91 \pm 1 \%)$ and less frequently positive for the HIV-1 co-receptor CXCR4 (3.5 \pm $2 \%)$ and galactosylceramide (GalCer) $(<1 \%)$. Unlike salivary gland epithelial cells [20], less than 1\% of TERT-2 cells expressed the CCR5 co-receptor for HIV-1. TE cells (tissue nos. 164, 193 and 196) were also analyzed for putative HIV-1 receptors and co-receptors (Table 1). TE cells did not express CD4, or CXCR4 or CCR5 $(<1 \%)$. When compared to TERT-2 cells, TE cells express GalCer $(4 \pm 0.1 \%)$ with similar frequency, but HSPGs $(13 \pm 7 \%)$ are expressed less frequently.

\section{TERT-2 oral keratinocytes support HIV-I reverse transcription and integration}

To demonstrate reverse transcriptase activity, we infected TERT-2 cells with pseudotype HIV-NL4-3 $\Delta$ env-EGFP particles, which express the vesiculostomatitis virus glycoprotein (VSV-G) envelope (virus-like particles; VLPs). When infected, cells express EGFP as a reporter for HIV-1 LTR promoter activity and expression of viral-specific proteins. When TERT-2 cells were inoculated with VLPs at a MOI of 10, EGFP was expressed at a high level, confirming reverse transcriptase activity, LTR promoter activity and expression of new viral-specific proteins (reported by EGFP) (Fig. 2A). When the cells were pre-treated with increasing amounts of the viral inhibitor AZT ( 5 to $2500 \mu \mathrm{M}$ ), EGFP expression was inhibited in a dose-dependent manner (Fig. 2A). Integration and expression of HIV-1 specific proteins was stable since EGFP was expressed after 10 passages of TERT-2 cells (data not shown).

To estimate the kinetics of the HIV LTR promoter activity, EGFP expression was analyzed at indicated times post inoculation with VLPs (Fig. 2B). EGFP expression was first detected at approximately $18 \mathrm{~h}$ post inoculation and max- imized at $48 \mathrm{~h}$, reflecting the time course of activation of the HIV LTR promoter in infected cells.

To confirm HIV-1 integration in TERT- 2 cells, we infected TERT-2 monolayers with HIV-1 strains IIIb or BaL and then performed a nested PCR with HIV- and human aluspecific primers (Table 2). These PCR reactions amplify HIV-1 sequences integrated in human genomic DNA. In preliminary experiments, we showed that laboratory stocks of HIV-1 are contaminated with DNA that is acquired from PBMCs during viral propagation (data not shown). The contaminating DNA was substantially resistant to DNase treatment of the HIV-1 stocks and could be amplified as a false-positive indication of integration. To eliminate contaminating sources on the plasma membrane or in the cytoplasm, integrated HIV-1 DNA was extracted directly from TERT-2 cell nuclei.

Infected TERT-2 nuclei contained integrated copies of HIV-1 from HIV strains IIIb and BaL, but only IIIb is shown (Fig. 3). Nested-PCR products were detectable in TERT- 2 cell nuclei between 3 and $72 \mathrm{~h}$ post inoculation. An attenuated signal persisted after subculturing the cells for 1 to 3 passages, showing that integration is stable. Nuclei extracted from ACH-2 cells, an $\mathrm{HIV}_{\mathrm{LAV}}$ latent T cell clone [33], and HIV-infected PBMCs also contained HIV integrated DNA and served as positive controls. In contrast, integrated HIV-1 DNA was not detected in TERT-2 nuclei incubated in the absence of HIV-1 (NV), when HIV1 was heat-inactivated (HV), or when cells were pretreated with AZT $(500 \mu \mathrm{M})$ or colchicine $(500 \mu \mathrm{M})$.

From 3 to $72 \mathrm{~h}$ post inoculation, but not after subculture, total linear HIV DNA was detected in the nuclei of TERT2 cells but not in the negative controls. Consistent with the low level of integration, HIV DNA two-LTR circles were not detected in TERT- 2 cells except for a weak signal at $6 \mathrm{~h}$ post inoculation and not detected in the negative controls. When TERT-2 cells were pre-treated with increas- 


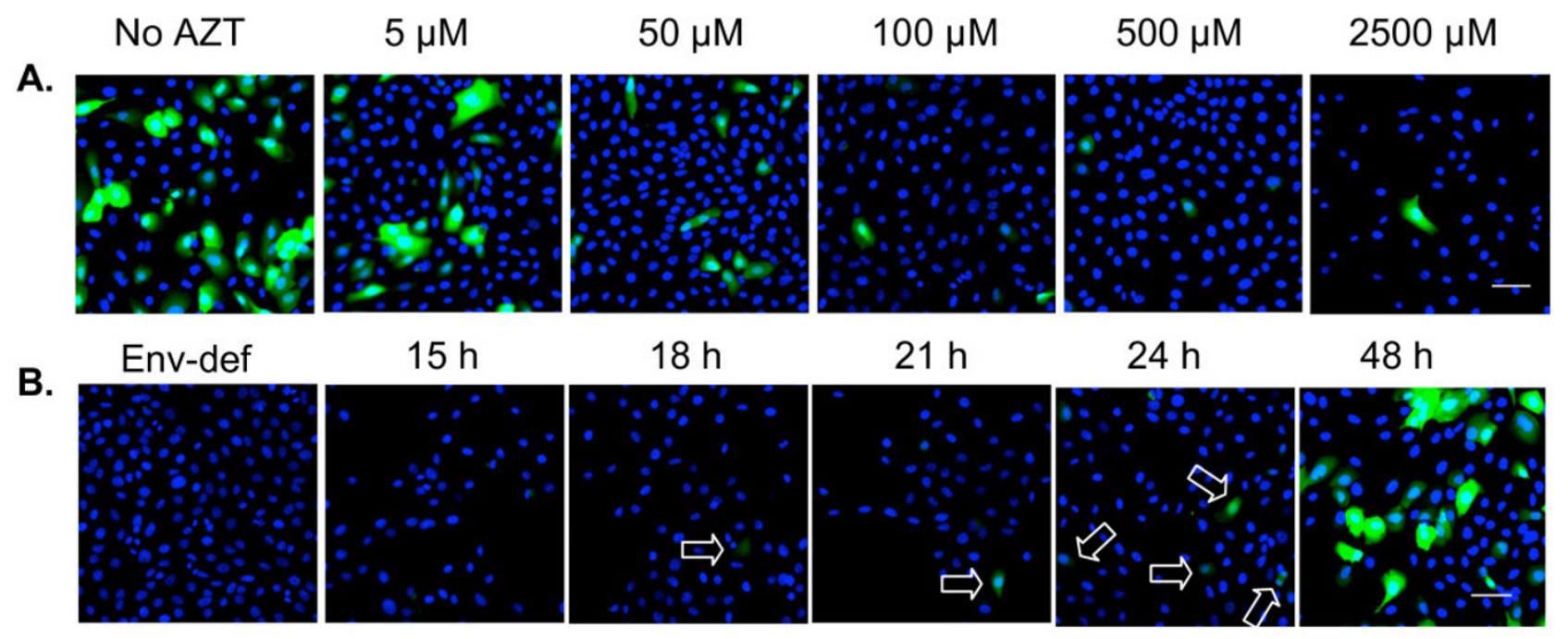

\section{Figure 2}

Replication-incompetent HIV-NL4-3 $\Delta$ env virus-like particles infect TERT-2 keratinocytes. Replication-incompetent HIV-NL4-3 $\Delta$ env virus-like particles (VLPs) were packaged in 293T cells to express VSV-G protein as described in Materials and Methods. The TCID 50 of VLPs was determined by titration in TZM-bl cells, and TERT-2 monolayers were then incubated for $6 \mathrm{~h}$ with VLPs at a MOI 10 (TCID 50 per cell). Cells were then washed, trypsinized to remove unincorporated VLPs, and incubated for up to $48 \mathrm{~h}$. Post inoculation, cells were fixed in $2 \%$ paraformaldehyde and nuclei were stained with DAPI (blue). (A) TERT-2 cultures were pre-incubated with AZT ( 0 to $2500 \mu \mathrm{M}$ ) before inoculation with VLPs. The expression of EGFP reporter gene was analyzed at $48 \mathrm{~h}$ post inoculation. (B) Kinetics of EGFP expression from $18 \mathrm{~h}$ to $48 \mathrm{~h}$ post inoculation. TERT-2 cells incubated with envelope-deficient particles were included as a negative control ( $48 \mathrm{~h}$ post inoculation). Arrows indicate EGFP expressing TERT-2 cells (green). Scale bar represent $50 \mu \mathrm{m}$. Images are representative of three independent experiments.

ing doses of AZT for $2 \mathrm{~h}$ followed by incubation with HIV1 for 6 h, integration of HIV-1 DNA was inhibited. Results with BaL were similar (not shown).

\section{New HIV RNA transcripts in TERT-2 cells}

Using RT-PCR, we attempted to detect new HIV-specific transcripts, including multiply spliced HIV-1 RNA, unspliced HIV-1 RNA, and U3-U5 HIV-1 RNA in TERT-2 cells. TERT- 2 cells were incubated with HIV-1 IIIb or BaL for $6 \mathrm{~h}$, trypsinized, washed, and incubated for up to $72 \mathrm{~h}$. Some cells were sub-cultured after infection. Although we detected multiply spliced and unspliced products when using specific primers, these transcripts could not be distinguished clearly from contamination (data not shown). Multiply spliced and unspliced HIV-1 RNA appeared to degrade and were not detected after $12 \mathrm{~h}$ post inoculation. HIV-1 RNA species were also undetected after cells were sub-cultured and U5-U3 HIV-1 RNA was not detected at any time (data not shown).

New HIV-specific transcript levels were also estimated by SYBR real time RT-PCR relative to the level in the viral inoculum (data not shown). Relative to levels in the viral inoculum, multiply spliced and singly spliced HIV-1 RNAs were barely detectable.

HIV-18ag-specific RNA, however, was detectable. Using real time RT-PCR, HIV ${ }^{a}$ g-specific RNA was quantified and the expression relative to $0 \mathrm{~h}$ was determined (Fig. 4). In TERT-2 cells, HIV ${ }^{a g}$-specific RNA appeared to increase up to $6 \mathrm{~h}$ post inoculation, suggesting that HIV-1 binds and enters TERT- 2 cells. By 24 h post inoculation, however, the amount of HIVsag-specific RNA declined below the level of detection. If replication occurred, HIV-18ag-specific RNA was expected to increase during the $72 \mathrm{~h}$ incubation. The HIV-18ag-specific RNA decayed over time, however, and was not a product of new transcriptional events. In TERT- 2 cells, therefore, RNA products of the HIV replication cycle were not prominent and replication appeared to abort.

\section{HIV-I harboring in TERT-2 keratinocytes}

To study harbored HIV-1, TERT-2 monolayers were incubated with HIV-1 for $6 \mathrm{~h}$, then trypsinized, and washed to eliminate non-internalized viral particles. TERT-2 monolayers were maintained in culture for the indicated times 
Table 2: Primer sequences and PCR conditions

\begin{tabular}{|c|c|c|c|}
\hline Target & Primer & Sequences (5'-3') & PCR conditions \\
\hline \multicolumn{4}{|l|}{ Integrated HIV-I } \\
\hline \multicolumn{4}{|l|}{ DNA $^{a}$} \\
\hline \multirow[t]{3}{*}{ - First round PCR } & L-M667 & $\begin{array}{l}\text { ATGCCACGTAAGCGAAACTCTGGCTAACT } \\
\text { AGGGAACCCACTG }\end{array}$ & $\begin{array}{l}95^{\circ} \mathrm{C}, 8 \mathrm{~min} \text { and } 95^{\circ} \mathrm{C}, 10 \mathrm{~s}, 60^{\circ} \mathrm{C}, 10 \mathrm{~s}, 72^{\circ} \mathrm{C} \text {, } \\
170 \mathrm{~s} \text { for } 12 \text { cycles }\end{array}$ \\
\hline & Alu I & TCCCAGCTACTGGGGAGGCTGAGG & \\
\hline & Alu 2 & GCCTCCCAAAGTGCTGGGATTACAG & \\
\hline \multirow[t]{2}{*}{ - Second round PCR } & Lambda T & ATGCCACGTAAGCGAAACT & $\begin{array}{l}95^{\circ} \mathrm{C}, 8 \mathrm{~min} \text { and } 95^{\circ} \mathrm{C}, 10 \mathrm{~s}, 60^{\circ} \mathrm{C}, 10 \mathrm{~s}, 72^{\circ} \mathrm{C}, 9 \mathrm{~s} \\
\text { for } 40 \text { cycles }\end{array}$ \\
\hline & AA55M & GCTAGAGATTTTCCACACTGACTAA & \\
\hline \multirow[t]{2}{*}{ Linear HIV DNAa } & MH53I & TGTGTGCCCGTCTGTTGTGT & $\begin{array}{l}95^{\circ} \mathrm{C}, 8 \mathrm{~min} \text { and } 95^{\circ} \mathrm{C}, 10 \mathrm{~s}, 60^{\circ} \mathrm{C}, 10 \mathrm{~s}, 72^{\circ} \mathrm{C}, 6 \mathrm{~s} \\
\text { for } 40 \text { cycles }\end{array}$ \\
\hline & MH532 & GAGTCCTGCGTCGAGAGAGC & \\
\hline \multirow[t]{2}{*}{ 2-LTR circle a $^{2}$} & HIV F & GTGCCCGTCTGTTGTGTGTGACT & $\begin{array}{l}95^{\circ} \mathrm{C}, 8 \mathrm{~min} \text { and } 95^{\circ} \mathrm{C}, 10 \mathrm{~s}, 60^{\circ} \mathrm{C}, 10 \mathrm{~s}, 72^{\circ} \mathrm{C}, 10 \\
\mathrm{~s} \text { for } 40 \text { cycles }\end{array}$ \\
\hline & HIV R & ACTGGTACTAGCTTGTAGCACCATCCA & \\
\hline \multirow[t]{2}{*}{ U5-U3 RNAa } & HIV F & GTGCCCGTCTGTTGTGTGTGACT & $\begin{array}{l}95^{\circ} \mathrm{C}, 2 \text { min and } 95^{\circ} \mathrm{C}, 5 \mathrm{~s}, 60^{\circ} \mathrm{C}, 10 \mathrm{~s}, 72^{\circ} \mathrm{C}, 10 \mathrm{~s} \\
\text { for } 40 \text { cycles }\end{array}$ \\
\hline & HIV R & ACTGGTACTAGCTTGTAGCACCATCCA & \\
\hline \multirow[t]{2}{*}{ Gag } & For & CCCATAGTGCAGAACATCCA & $\begin{array}{l}50^{\circ} \mathrm{C}, 2 \mathrm{~min}, 95^{\circ} \mathrm{C}, 2 \mathrm{~min} \text {, and } 95^{\circ} \mathrm{C}, 15 \mathrm{~s} \text { and } \\
60^{\circ} \mathrm{C}, 30 \mathrm{~s} \text {, for } 50 \mathrm{cycles}\end{array}$ \\
\hline & $\operatorname{Rev}$ & GGGCTGAAAGCCTTCTCTTC & \\
\hline \multirow[t]{2}{*}{ Singly spliced ${ }^{b}$} & M669 & $\begin{array}{l}\text { GTGTGCCCGTCTGTTGTGTGACTCTGGTA } \\
\text { AC }\end{array}$ & $\begin{array}{l}50^{\circ} \mathrm{C}, 2 \mathrm{~min}, 95^{\circ} \mathrm{C}, 2 \mathrm{~min} \text {, and } 95^{\circ} \mathrm{C}, 15 \mathrm{~s} \text { and } \\
60^{\circ} \mathrm{C}, 30 \mathrm{~s} \text {, for } 50 \text { cycles }\end{array}$ \\
\hline & La 23 & GCCTATTCTGCTATGTCGACACC & \\
\hline \multirow[t]{2}{*}{ Multiply spliced HIV RNAa } & P659 & GACTCATCAAGTTTCTCTATCAAA & $\begin{array}{l}95^{\circ} \mathrm{C}, 4 \mathrm{~min} \text { and } 95^{\circ} \mathrm{C}, 5 \mathrm{~s}, 54^{\circ} \mathrm{C}, 10 \mathrm{~s}, 72^{\circ} \mathrm{C}, 8 \mathrm{~s} \\
\text { for } 40 \text { cycles }\end{array}$ \\
\hline & P4I3MOD & AGTCTCTCAAGCGGTGGT & \\
\hline \multirow[t]{2}{*}{ Unspliced HIV RNAa } & La 9 & GACGCTCTCGCACCCATCTC & $\begin{array}{l}95^{\circ} \mathrm{C}, 2 \text { min and } 95^{\circ} \mathrm{C}, 10 \mathrm{~s}, 60^{\circ} \mathrm{C}, 40 \mathrm{~s} \text { for } 40 \\
\text { cycles }\end{array}$ \\
\hline & La 8.1 & CTGAAGCGCGCACGGCAA & \\
\hline \multirow[t]{2}{*}{$\beta$-actin } & Actin $\mathrm{F}$ & ATGGCCACGGCTGCTTCCAGC & $95^{\circ} \mathrm{C}, 15 \mathrm{~s}, 55^{\circ} \mathrm{C}, 30 \mathrm{~s}, 72^{\circ} \mathrm{C}, 15 \mathrm{~s}$ for 30 cycles \\
\hline & Actin $\mathrm{R}$ & CATGGTGGTGCCGCCAGACAG & \\
\hline \multirow[t]{2}{*}{ GAPDH } & GAPDH F & GAGTCAACGGATTTGGTCGT & $95^{\circ} \mathrm{C}, 15 \mathrm{~s}, 60^{\circ} \mathrm{C}, 30 \mathrm{~s}, 72^{\circ} \mathrm{C}, 15 \mathrm{~s}$ for 30 cycles \\
\hline & GAPDH R & TTGATTTTGGAGGGATCTCG & \\
\hline
\end{tabular}

a Primer sequences and PCR conditions were modified from [40]

b Primer sequences and PCR conditions were modified from [74]

up to $120 \mathrm{~h}$ post inoculation. To determine release of infectious virions, TERT-2 cell supernatants were aspirated (contains HIV-1 released from TERT-2 cells) and inoculated into PHA-activated PBMCs. After the infectious supernatants were aspirated, the TERT-2 cells were co-cultured separately with PHA-activated PBMCs to determine harbored virus available for direct transfer. TERT-2 cells appeared to harbor and trans infect X4- and R5 HIV-1 to permissive PBMCs (Fig. 5A). In contrast, supernatants from TERT-2 monolayers were barely infectious (Fig. 5B). HIV-1 trans infection by TERT-2 cells decreased to undetectable levels at $48 \mathrm{~h}$ (Fig. 5A and 5B), suggesting that harbored virus had decayed.

\section{MOLT-4/CCR5 cells acquire VLPs from infected TERT-2 cells}

To confirm that PBMCs acquire HIV-1 primarily by cellto-cell interactions, TERT-2 cell monolayers were inocu-

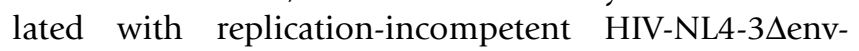

EGFP particles (VLPs) for $6 \mathrm{~h}$ at MOI 100. These VLPs replicate for a single round in the cell that ultimately becomes infected. TERT-2 cells with harbored, non-replicating HIV VLPs do not express EGFP. TERT-2 cells were then co-cultured with permissive MOLT-4/CCR5 $\mathrm{T}$ cells (MOLT-4/CCR5). VLP trans infection was determined by EGFP expression in MOLT-4/CCR5 at $48 \mathrm{~h}$ after co-culture. At $6 \mathrm{~h}$ post inoculation, TERT-2 cells captured and transferred $56 \%$ of the VLP inoculum to infect MOLT-4/ CCR5 (Fig. 6). When TERT-2 cells were treated with trypsin at $6 \mathrm{~h}$ and washed to inactivate and remove extracellular virus, $18 \%$ of the VLP inoculum was transferred from within the TERT-2 cells to infect co-cultured MOLT4/CCR5 cells. When TERT-2 cells were treated with colchicine ( $500 \mu \mathrm{M}$ for $30 \mathrm{~min}$ before inoculation) to uncouple the tubulin cytoskeleton, $18 \%$ of the VLP inoculum was harbored and transferable to MOLT4 cells. At $4{ }^{\circ} \mathrm{C}, 7 \%$ was harbored by untreated TERT-2 cells. A small percentage of VLPs were resistant to trypsin and colchicine treat- 


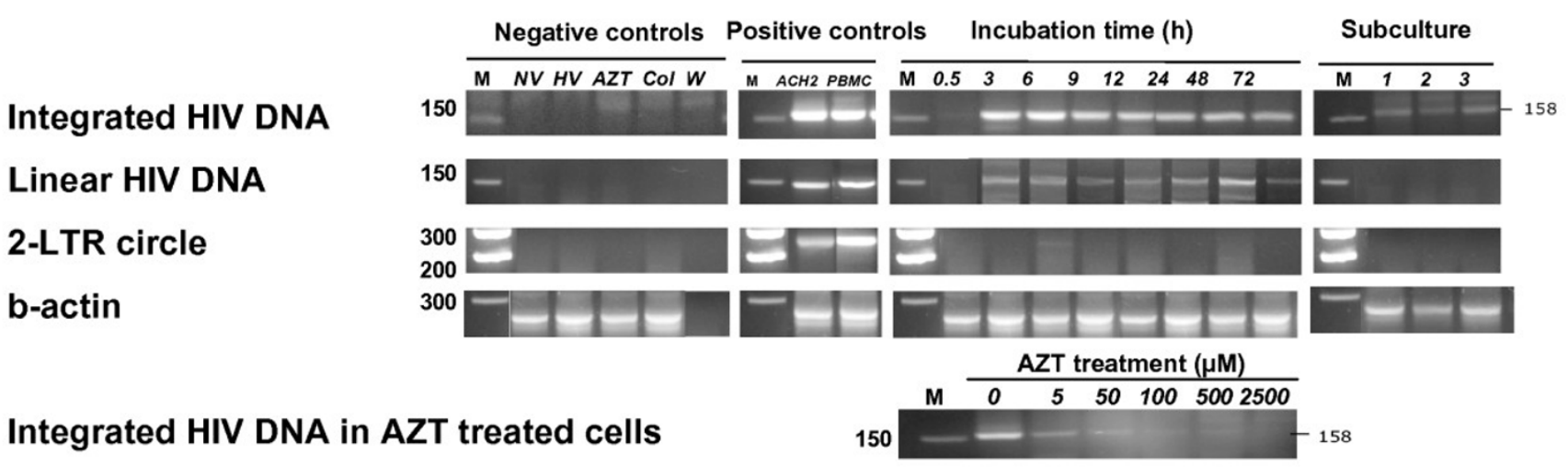

\section{Figure 3}

Integrated HIV-I DNA detected in TERT-2 nuclei. TERT-2 cells were grown in monolayers and inoculated with HIV-I (Illb or BaL). Some cells were sub-cultured after infection. At 0.5 to $72 \mathrm{~h}$ post inoculation, TERT-2 cell nuclei were isolated as described in Materials and Methods. DNA was extracted from the nuclei and analyzed for integrated HIV DNA, linear HIV DNA, and 2-LTR circular HIV DNA. $\beta$-actin was included as a loading control. PCR reactions were performed as described in Materials and Methods (Table 2). Negative controls include cells without HIV-I (NV), cells inoculated with heat-inactivated HIV-I (HV), cells pretreated with $500 \mu \mathrm{M}$ AZT (AZT), cells pretreated with colchicine (Col), and PCR reactions with no template (W). PBMC media (uninfected with HIV-I) and samples that were amplified in the second PCR only were also negative for HIV DNA (data not shown). ACH-2 cells and HIV-I-infected PBMCs served as positive controls for detection of integrated HIV DNA, linear HIV DNA, and circular HIV DNA. These agarose gel data for HIV-I IIIb infection are representative of three independent experiments.

ments, infecting MOLT-4/CCR5 cells (4\%) when cocultured with TERT-2 cells. VLPs could bind TERT- 2 cells at $4^{\circ}$ or $37^{\circ} \mathrm{C}$, but VLPs could be internalized efficiently

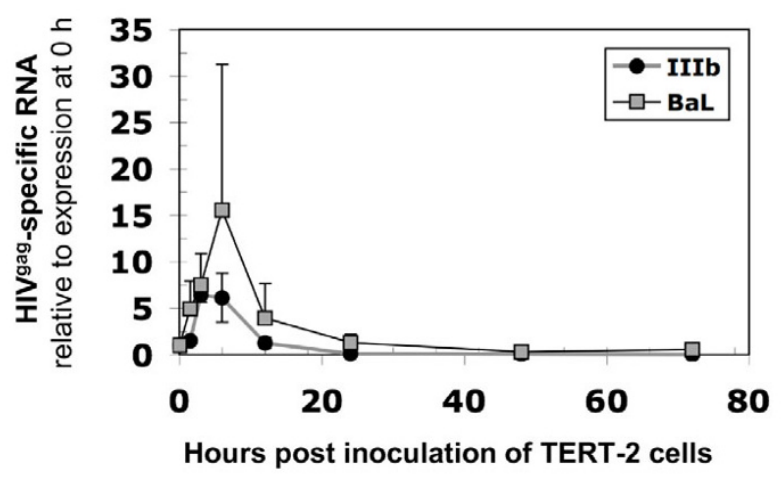

\section{Figure 4}

HIV infection aborted in TERT-2 keratinocytes.

TERT-2 cell monolayers were incubated with HIV-I (IIlb or $\mathrm{BaL})$, trypsinized and washed. Cells were sub-cultured at 48 $\mathrm{h}$ post incubation. At 0.5 to $72 \mathrm{~h}$ post incubation, total RNA was isolated and CDNA was synthesized as described in the Materials and Methods. HIVgag-specific RNA was detected by SYBR real time PCR. $\beta$-actin served as the reference housekeeping gene. Data are the mean \pm standard deviation of three independent experiments, each performed in triplicate. only at $37^{\circ} \mathrm{C}$ suggesting that microtubule activity was required for internalization. The fraction of VLPs that resisted trypsinization and were sensitive to cold and colchicine appeared to be harbored within TERT-2 cells and transferred to MOLT4/CCR5 cells by direct cell-to-cell interactions.

\section{Discussion}

Lining the oral and oropharyngeal mucosal surfaces, oral keratinocytes are potential targets for primary HIV-1 infection, harboring and dissemination. We now show for the first time that oral keratinocytes harbor and transfer viable HIV-1 to infect permissive cells for up to $48 \mathrm{~h}$. Therefore, HIV-1 internalization by oral keratinocytes in vitro $[18,20,22,34]$ may model an overlooked mechanism for HIV transmission and dissemination in vivo.

Although conventional wisdom suggests that primary human infection of permissive cells actually occurs in the gut $[9,35]$, the oral mucosa in primate models becomes infected within a day of atraumatic oral mucosal exposure to SIV-1 $[8,36]$. Infection becomes marked in the GI tract four days after initial exposure, suggesting that virus disseminates from an oral focus.

Among oral mucosal sites, palatine tonsils are likely to disseminate HIV-1 since tonsil epithelial cells express appropriate receptors in situ $[37,38]$, and trans infect HIV- 

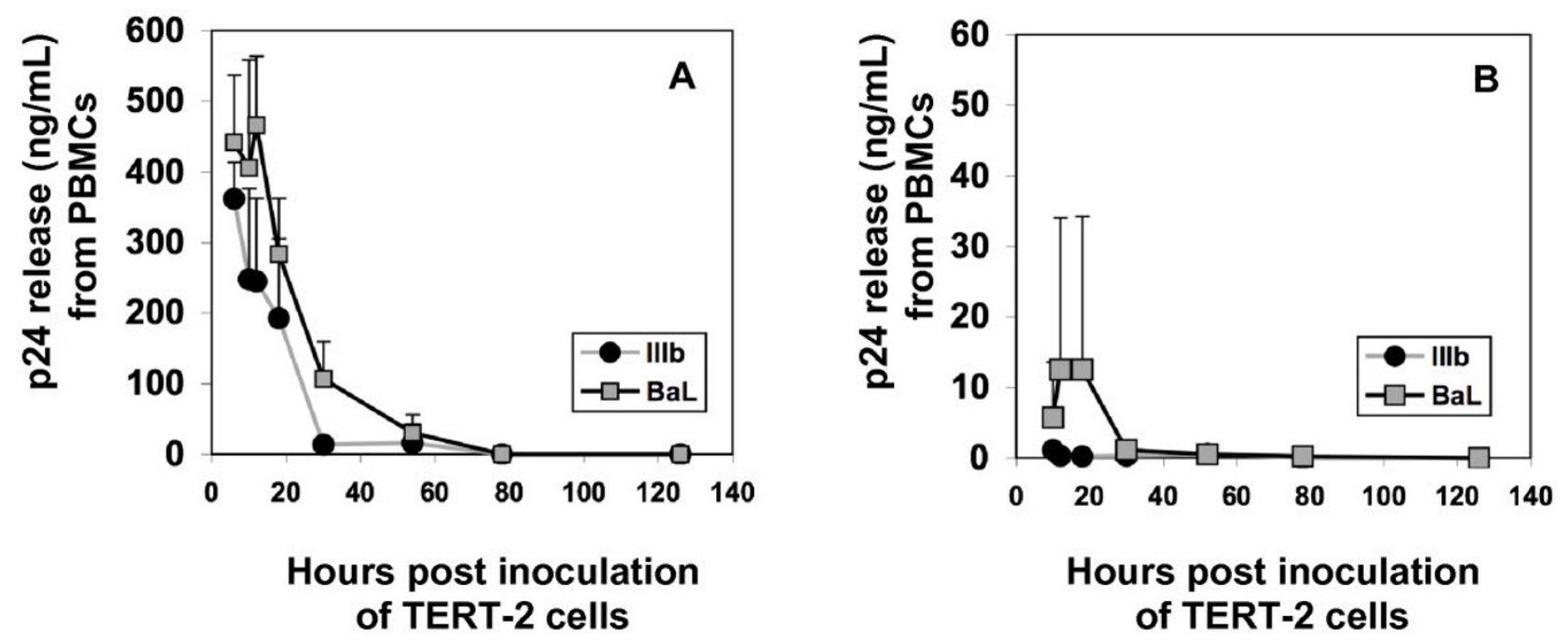

\begin{abstract}
Figure 5
Infectious HIV-I harbored by TERT-2 cells. TERT-2 monolayers were incubated for 6 h with HIV-I (IIlb or BaL). TERT2 cells were then trypsinized, washed, and maintained in growth media. At the indicated time post inoculation, TERT- 2 cells were co-cultured with (A) PHA-activated PBMCs to test for direct transfer of HIV-I. To learn if infectious HIV-I is released from TERT-2 cells, (B) spent media were recovered and used to inoculate PHA-activated PBMCs. After exposure to TERT-2 cells or media, PBMC supernatants were harvested at day 9 and analyzed for p24gag production by ELISA. Data shown are the mean \pm standard deviation from three independent experiments, each performed in triplicate.
\end{abstract}

1 to permissive cells in vitro. HIV trans infection in vitro from primary TE cells to PBMCs showed variation among tonsil donors. Since TE cells were derived from excised tonsils obtained with uncharacterized inflammatory backgrounds, proinflammatory cytokines might be differentially expressed in TE cells. Some cytokines may modulate HIV entry (reviewed in [39]), but whether donorspecific expression patterns affect primary infection is not known. Clearly, keratinocyte-associated virions remain infectious and can be transferred to infect co-cultured permissive cells.

Oral keratinocytes support the life cycle of HIV-1 step-bystep until integration. HIVgag-specific RNA peaked in TERT- 2 cells after a $6 \mathrm{~h}$ incubation with HIV-1, which is consistent with the internalization of HIV-1 genomic RNA over time (Fig. 4; [40]). After internalization in TERT-2 cells, HIV-1 begins a replication cycle, which is not completed. HIV-1 genomic RNA is reverse transcribed into DNA, which can be inhibited by treatment of the cells with AZT (Fig. 2A). Among other reverse transcriptase products, linear HIV DNA was detected in oral keratinocytes, whereas two-LTR circles, stable forms of unintegrated HIV DNA, were not seen. This pattern of products is consistent with the low level of HIV-1 integration into TERT2 cell genomic DNA.
To clarify the viral life cycle in TERT-2 cells, the presence of integrated HIV DNA was sought as a product of reverse transcriptase activity. Integrated HIV DNA was consistently detected in TERT-2 cell nuclei (Fig. 3). After incubation with HIV-1 in vitro, Liu et al. [20] had previously reported that oral keratinocytes contain linear HIV-specific DNA. We noted that contaminating DNA from the propagating cells is present in the viral inoculum and can be amplified by nested PCR, giving a false indication of integration. To avoid this artifact, we isolated HIV-1 DNA directly from the TERT-2 cell nuclei. As previously reported in permissive cells [40], integrated HIV DNA is detected consistently in TERT-2 nuclei and in all keratinocyte lines tested (data not shown) as early as $3 \mathrm{~h}$ post inoculation (Fig. 3). Integrated HIV DNA persisted in the TERT-2 genome after several passages of the cells, but the signal decayed for linear HIV DNA. To this point, replication kinetics in oral keratinocytes and permissive cells [40] were similar. The HIV-1 life cycle in TERT-2 cells was marked by viral internalization, uncoating, reverse transcriptase and integrase activities.

In response to infection by HIV-1 IIIb or BaL, the rate of decay of nonintegrated linear HIV-1 DNA in TERT-2 cells appeared to be too rapid to support substantial gene expression [40]. Likewise, we were unable to detect the 


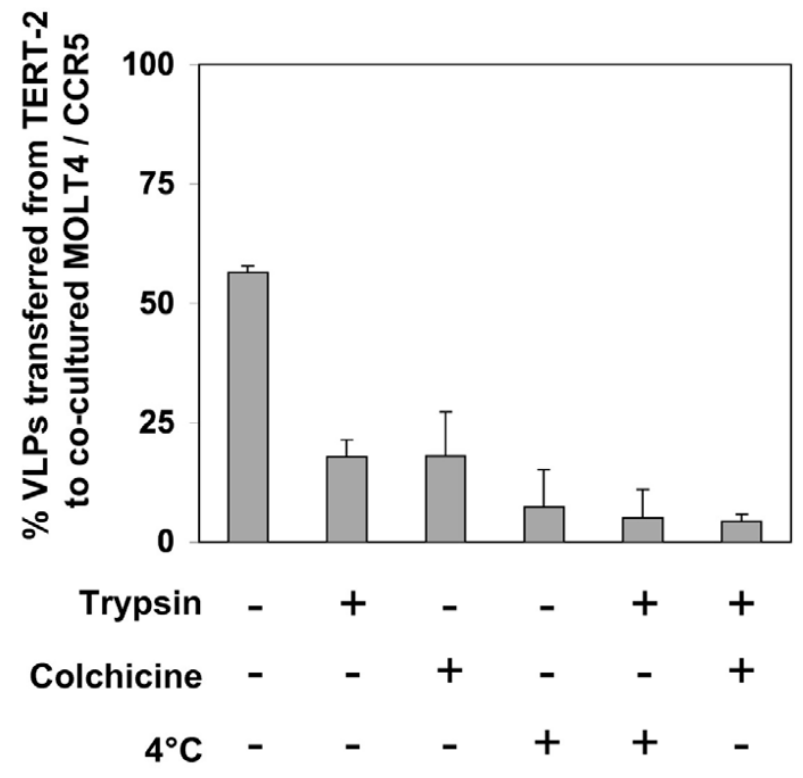

\section{Figure 6}

TERT-2 cells trans infect VLPs to MOLT-4/CCR5 cells. TERT-2 cell monolayers were incubated for $6 \mathrm{~h}$ at $37^{\circ} \mathrm{C}$ with replication-incompetent HIV-NL4-3 particles pseudotyped to express VSV-G envelope (VLPs) at a MOI 100. Cells were washed, then co-cultured with MOLT-4/ CCR5 $\left(2 \times 10^{5}\right)$ cells, and EGFP expression in MOLT-4/ CCR5 cells was analyzed at $48 \mathrm{~h}$ using flow cytometry. The percentage of infected MOLT-4/CCR5 cells was quantified. Some TERT-2 monolayers were either treated with trypsin, colchicine (500 $\mu \mathrm{M}$ for $30 \mathrm{~min}$ ), pre-cooled to $4^{\circ} \mathrm{C}$, trypsin and pre-cooled to $4^{\circ} \mathrm{C}$, or trypsin and colchicine as described in the Materials and Methods. Data shown are the mean \pm standard deviation from three independent experiments.

specific RNA product U5-U3 RNA. HIV-1 specific mRNAs appeared at levels that could not be clearly distinguished from contamination (data not shown). After low-level integration, therefore, HIV-1 replication aborts.

Many steps in the HIV life cycle may be restricted by intrinsic cellular factors targeting viral entry, viral uncoating, viral DNA synthesis, intracellular trafficking of viral nucleic acids, integration, viral gene expression or viral packaging [41]. TERT-2 cells clearly restrict HIV replication after integration when infected with HIV-1. We sought to determine whether the internalization pathway used by HIV-1 in TERT-2 cells contributed to the restriction. Therefore we inoculated TERT-2 cells with VSV-G

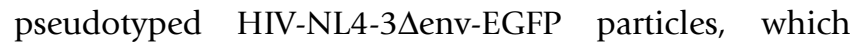
internalizes promiscuously into an endosomal pathway [42]. When integrated, HIV LTR from the pseudotyped particles regulates green fluorescence expression in TERT2 cells (Fig. 3A and 3B). When the conventional, gp120- mediated viral entry is circumvented, the VSV-pseudotyped HIV-1 particles integrate and new RNA is transcribed. Since EGFP is expressed, viral-specific proteins are likely to be synthesized. This is in contrast to infection with the wild-type HIV-1 strains, where new transcripts are minimally expressed. Hence the CD4- and CCR5-independent internalization may represent a major restriction against HIV-1 replication.

The HIV entry mechanisms in oral keratinocytes and other epithelial cells are not well understood. Unlike oral keratinocytes, gastrointestinal epithelial cells constitutively express CCR5 and selectively internalize R5-tropic HIV-1 [43]. Oral keratinocytes from different sources are CD4and express different putative receptors and co-receptors for HIV-1 including galactosylceramide [20] and heparin sulfate proteoglycans (HSPGs) [37,44-51]. HSPG binds HIV-1 gp120 [16,47,52-54], which can enter endosomes $[55,56]$ and enable co-localization of HIV-1 particles with endosomal markers in TERT-2 cells (Dietrich E. et al, in preparation). Except for HSPGs, most putative receptors and co-receptors for HIV-1 are inconsistently expressed (Table 1) and can vary with the microanatomic location [37].

Although we saw no evidence of new HIV transcripts or newly replicated virions, TERT-2 cells clearly harbor infectious HIV-1 virions. Harbored HIV-1 can be effectively transferred to infect permissive cells including PBMCs for up to $48 \mathrm{~h}$, but appear to become less infectious during the interval from 6 to $48 \mathrm{~h}$ after inoculation. After $48 \mathrm{~h}$, TERT-2 cells were ineffective at trans infecting cell-associated harbored virus (Fig. 5A) and infectious supernatants (Fig 5B) to activated PBMCs. Since most experiments were performed after trypsinizing TERT-2 cells to remove extracellular virus, internalized HIV-1 was a harbored infectious reservoir.

HIV uptake and transfer are temperature and microtubule dependent (Fig. 6), as reported for endothelial cells [16]. With trypsin or colchicine treatment, harbored, internalized particles were distinguished from surface-bound particles. Both surface-bound and internalized particles are infectious and effectively trans infect CD4+ cells (Fig. 6). Cell-associated particles effectively trans infect PBMCs and MOLT-4 cells. Few infectious viral particles are released from TERT- 2 cells. Optimal HIV transfer from TERT- 2 cells is suggested therefore to involve direct cell-to-cell interactions with PBMCs and other permissive cells.

In the oral mucosa, the transfer of infectious virus to proximal lymphoid cells may be of clinical importance. Proximal to mucosal stratified squamous keratinocytes, Langerhans cells and CD4-positive lymphocytes are available to be trans infected in vivo. Indeed, a recent report 
suggests that Langerin-positive dendritic cells degrade internalized HIV-1, reducing transfer to CD4+ T cells in the mucosa [57], while others show that activated CD34positive Langerhans cells increase trans infection of permissive target cells [58]. Unlike the female genital epithelium [17], oral Langerhans cells (dendritic cells) are not known to sample antigens or capture HIV-1 at the mucosal surface. Oral mucosal keratinocytes, therefore, could contribute to HIV transmission in vivo, however, by activating and trans infecting Langerhans cells, which can dock and transfer virus to CD4+ cells, or by transferring infectious harbored HIV-1 particles to proximal permissive cells.

For the first time, we show that oral keratinocytes become infected by HIV-1, initiating a defined, truncated viral life cycle. While infection is non-productive, an intracellular pool of infectious HIV-1 is harbored for up to $48 \mathrm{~h}$ and fully capable of trans infecting CD4+ permissive cells. Hence, the oral epithelium may actively disseminate HIV1 infection and is more than an inert barrier. Since R5tropic HIV-1 is most frequently associated with primary infections, oral epithelium could function as a selective "gatekeeper" and exclude X4-tropic virus. When compared, oral keratinocytes from different sources selectively harbor and transfer HIV-1 in either an X4- or R5-tropic HIV-1-specific manner (data not shown). TERT-2 cells consistently harbor all HIV-1 strains tested, while primary tonsil epithelial cells from some donors did not support trans infection (Fig. 1A). Since CXCR4+ CCR5- TERT-2 cells (Table 1) appear to harbor R5-tropic HIV-1 BaL more effectively than IIIb (Fig. 4), infection appears to be independent of the co-receptor tropism of the HIV envelope protein. We have recently shown that the endogenous oral pathogen, Porphyromonas gingivalis, selectively up-regulates CCR5 on CXCR4+ oral keratinocytes [59]. Up-regulation of CCR5 selectively promotes the harboring and transfer of R5-tropic HIV-1 from TERT-2 cells to permissive targets [60].

If oral mucosal keratinocytes serve as a clinical focus for HIV-1 infection, endogenous restriction factors notwithstanding, novel uptake, harboring and transfer mechanisms may become potential targets for antiviral drugs and vaccines. Following the initial short period of primary virus exposure, infectious HIV-1 persists in oral keratinocytes for several days. The harbored virus could be transferred to permissive cells and arguably serve to disseminate infection systemically. In the oral cavity, salivary components have been suggested to reduce the risk of HIV transmission [61-63]. For example, salivary mucins agglutinate the virus in vitro and appear to reduce viral uptake into permissive cells [64]. In the presence of saliva, however, HIV-1 still internalizes into oral keratinocytes in vitro and infectious virus can be effectively transferred to permissive reporter cells (Dietrich et al, 2008 in preparation). The rate of uptake of infectious HIV-1 into oral keratinocytes in the presence of saliva appears to occur more rapidly than complete inactivation of virus. Even in the presence of saliva, shedding oral epithelial cells may also serve as an infectious source for HIV transmission during oral sexual contacts. To protect against mucosal HIV transmission and dissemination, therefore, mucosal vaccines and microbicides should target the viral reservoir in oral keratinocytes.

\section{Conclusion}

The oral mucosa is exposed to infectious HIV-1 during oral-sexual contact and breast-feeding. The surface oral and oropharyngeal epithelium is a potential site of primary HIV infection and dissemination even though these cells do not express the common HIV-1 receptors and coreceptors found on permissive cells. Using an atypical uptake mechanism (CD4-independent), oral epithelial keratinocytes were hypothesized to capture or internalize infectious HIV-1 and reverse transcribe the RNA HIV-1 genome into DNA, which then integrates into the keratinocyte genome. For the first time, integration, a major feature of infection, is shown to persist in daughter cells after the keratinocytes divide. After integration, the life cycle of the virus aborts and no newly assembled virus particles are detectable. By using HIV-1 that was engineered to bypass the usual receptors, we showed that the virus life cycle is prolonged. Although the life cycle aborts, captured infectious HIV-1 is harbored for at least $48 \mathrm{~h}$ and transferred to highly permissive peripheral blood mononuclear cells, which in vivo could result in systemic CD4+ T cell infection. While often considered passive bystanders in HIV-1 infection, mucosal epithelial cells could be actively providing a route to systemic infection.

\section{Materials and methods \\ Cells}

OKF6/TERT-2 immortalized keratinocytes (TERT-2), provided by Dr. James G. Rheinwald (Harvard Medical School, MA) were cultured in Keratinocyte-SFM (Invitrogen) supplemented (to final concentrations) with $0.2 \mathrm{ng} /$ $\mathrm{mL}$ recombinant epidermal growth factor (rEGF; Invitrogen), $25 \mu \mathrm{g} / \mathrm{mL}$ bovine pituitary extract (BPE), and 0.4 $\mathrm{mM} \mathrm{CaCl}_{2}$. Tonsil epithelial cells (TE) were isolated from tissue excised from HIV-seronegative individuals undergoing tonsillectomy at Hennepin County Medical Center, Minneapolis, MN. Use of surgical waste TE cells in research was reviewed and approved by the Research and Development Committee of the Minneapolis VA Medical Center and the Human Subjects Research Committee of the Hennepin County Medical Center. The protocol was determined to be exempt upon full IRB review and no subject consent was necessary. For culture, tonsillar epithelial cells were prepared by a modified method of Oda 
and Watson [65]. Briefly, tissue was cut and digested at $4{ }^{\circ} \mathrm{C}$ overnight in $0.2 \%$ Dispase grade II (Boehringer Mannheim) in MEM supplemented with 10\% FBS. The next day, epithelial sheets were separated from connective tissue, digested using $0.05 \%$ Trypsin/0.53 mM EDTA (GIBCO) at $37^{\circ} \mathrm{C}$ for $5 \mathrm{~min}$, and dispersed into single cell suspensions using a pipette. Cells were cultured in keratinocyte-SFM supplemented with $5 \mathrm{ng} / \mathrm{mL} \mathrm{hEGF,} 30 \mu \mathrm{g} / \mathrm{mL}$ $\mathrm{BPE}$, and $0.06 \mathrm{mM} \mathrm{CaCl}_{2}$. For use in the experiments, TE cells from passage 3 or 4 were seeded at $10^{4}$ cells $/ \mathrm{cm}^{2}$. Molt-4/CCR5, ACH2, and TZM-bl cells were provided by the NIH AIDS Research and Reference Program. MOLT-4/ CCR5 T cells were cultured in RPMI medium 1640 (Invitrogen) supplemented with 10\% FBS and $1 \mathrm{mg} / \mathrm{mL}$ G418 sulfate. TZM-bl, and 293T were cultured in Dulbecco's Modified Eagle Medium (D-MEM; Invitrogen) containing 10\% FBS. Peripheral blood mononuclear cells (PBMCs) were isolated from buffy coats obtained from 10 healthy seronegative donors by Ficoll-Histopaque density gradient centrifugation [66] and cryopreserved in liquid nitrogen until use. Source leukocytes from healthy adult donors were purchased from the Memorial Blood Centers. The Memorial Blood Centers IRB reviewed and approved the protocol. As part of the consent process, the blood donors agreed that their donated blood could be used for research purposes. When needed, PBMCs $\left(2 \times 10^{6}\right.$ cells/ $\mathrm{mL}$ ) were activated overnight in PBMC media (RPMI1640 medium containing L-glutamine (Mediatech, Inc.), 5\% human interleukin-2 (Roche) with 10\% FBS) supplemented with $5 \mu \mathrm{g} / \mathrm{ml}$ phytohemagglutinin (PHA-P; Sigma). After activation, cells were washed to remove PHA-P and cultured for 3 days in PBMC media before use.

\section{Viruses}

HIV-1 strains IIIB (X4-tropic) and BaL (R5-tropic) were obtained from the NIH AIDS Research and Reference Reagent program. HIV-1 was propagated and TCID $_{50}$ of virus stocks was determined in PHA-activated PBMCs as described in the Manual for HIV Laboratories, National Institutes of Health, Division of Acquired Immune Deficiency Syndrome (DAIDS) Virology (Publication NIH-973838).

\section{Virus-like particles}

Plasmids encoding non-replicative NL4-3 (pNL4-3- $\Delta$ envEGFP; Catalog number 11100) and the vesicular stomatitis virus G (VSV-G) glycoprotein (pHEF-VSV-G; Catalog number 4693) were obtained from NIH AIDS Research and Reference Reagent Program. To generate VLPs, 293T cells were transiently transfected with pNL4-3- $\Delta$ env-EGFP $(10 \mu \mathrm{g})$ and pHEF-VSV-G $(1 \mu \mathrm{g})$, using calcium phosphate precipitation as described previously [67]. To determine TCID $_{50}$ of VLPs, TZM-bl cells $\left(1 \times 10^{4}\right.$ cells/well $)$ were cultured overnight in 96-well tissue culture plates, and then incubated with six replicates of ten serial dilutions $(1: 4)$ of a VLPs stock in $50 \mu \mathrm{l}$ growth media per well with the addition of $10 \mu \mathrm{g} / \mathrm{mL}$ Sequa-brene (Sigma). After $2 \mathrm{~h}$, cells were washed three times and incubated in $200 \mu \mathrm{l}$ of growth media. After $48 \mathrm{~h}$, cells were fixed with $0.05 \%$ glutaraldehyde for $5 \mathrm{~min}$ at room temperature and washed twice with Dulbecco's phosphate-buffered saline (Mediatech, Inc.; DPBS). To detect the expression of $\beta$-galactosidase, cells were stained with $1 \mathrm{mg} / \mathrm{mL}$ X-Gal in $5 \mathrm{mM}$ $\mathrm{KFe}_{4}\left(\mathrm{CN}_{6}\right) 3 \mathrm{H}_{2} \mathrm{O}, 5 \mathrm{mM} \mathrm{KFe}{ }_{3}\left(\mathrm{CN}_{6}\right) 3 \mathrm{H}_{2} \mathrm{O}$, and $1 \mathrm{mM}$ $\mathrm{MgCl}_{2}$ and incubated at $37^{\circ} \mathrm{C}$ for $2 \mathrm{~h}$. A positive well contained two or more blue cells. Positive- and negativestained wells were tabulated and TCID $_{50}$ was calculated using the Reed-Muench TCID $_{50}$ calculation [68].

\section{Flow cytometry}

TERT-2 or TE cells were washed once with DPBS and incubated with $0.02 \%$ (W/V) EDTA for $10 \mathrm{~min}$. Detached cells were washed twice with DPBS supplemented with 2\% FBS (wash buffer), and resuspended at 5 to $10 \times 10^{5}$ cells in $200 \mu \mathrm{L}$ wash buffer. To identify putative HIV receptors and co-receptors, cells were incubated at $4^{\circ} \mathrm{C}$ for $30 \mathrm{~min}$ with $1 \mu \mathrm{g}$ of anti-CD104, CXCR4, CCR5, galactosylceramide (GalCer), heparin sulfate (HSPGs), DC-SIGN, or macrophage mannose receptor (Table 1). Similarly, to characterize the purity of primary tonsil keratinocytes in culture, antibodies against CD3, CD4, CD11a/LFA1, CD32, CD64, CD89, and human fibroblast were used (Table 1). All antibodies were obtained from BD Pharmingen, except anti-GalCer (Chemicon), antiheparin sulfate (Seikagaku) and anti-human fibroblasts (Sigma). Cells were then washed twice with $1 \mathrm{~mL}$ wash buffer to remove unbound antibody. If needed, cells were stained with goat anti-mouse IgG or IgM conjugated with fluorescein isothiocyanate (FITC) (Jackson ImmunoResearch Laboratories, West Grove, PA) in $200 \mu \mathrm{L}$ wash buffer at $4^{\circ} \mathrm{C}$ for $30 \mathrm{~min}$ to detect primary antibodies. Isotype controls and other staining controls were included. After staining, cells were washed three times with $1 \mathrm{~mL}$ wash buffer, fixed in $200 \mu \mathrm{L}$ of $2 \%$ paraformaldehyde, and stored at $4^{\circ} \mathrm{C}$ until analysis using a FACSVantage SE flow cytometer (BD Biosciences).

\section{HIV infection}

To infect with HIV-1, TERT-2 cells were plated in 96-well tissue culture plates $\left(1.5 \times 10^{4}\right.$ cells/well) and grown overnight in monolayers to $80-90 \%$ confluence and infected at a MOI 0.01 (TCID $_{50}$ per seeded cells), for 0.5 to $120 \mathrm{~h}$. Every 48 h, media were replaced with fresh growth media to maintain viability of TERT-2 and TE cells. In some experiments, viruses were heat-inactivated (HV) by incubating in a water bath at $70^{\circ} \mathrm{C}$ for $3 \mathrm{~h}$ and used as a negative control. At indicated times, HIV-1 was aspirated. To remove surface-bound HIV-1, some cultures were treated with $0.05 \%$ trypsin/ $0.53 \mathrm{mM}$ EDTA for $3 \mathrm{~min}$ at room temperature, and then an equal volume of soybean 
trypsin inhibitor $(250 \mu \mathrm{g} / \mathrm{mL}$; Invitrogen $)$ in HBSS was added. Trypsinization did not appear to disrupt the monolayers, which were washed three times in HBSS and maintained in growth media. Some cells were sub-cultured for 3 to 8 passages post inoculation. In some experiments, cells were pre-treated with azidothymidine (AZT; $500 \mu \mathrm{M}$; Sigma) for $2 \mathrm{~h}$, or colchicine (500 $\mathrm{MM}$; Sigma) for $30 \mathrm{~min}$ and then inoculated with HIV-1. Colchicine was washed from cultures before HIV-1 was added, but AZT remained with TERT-2 cells during HIV incubation. To determine if reagent carry over inhibited replication in permissive cells, colchicine or AZT was incubated with TERT-2 cells. The treated and untreated TERT- 2 cells were co-cultured with MOLT-4/CCR5 cells and VLPs (see below). Infectivity of VLPs (EGFP expression) in MOLT-4/ CCR5 cells was similar when co-cultured with TERT-2 cells in the presence or absence of AZT, suggesting that contamination from TERT-2 cell cultures was insufficient to inhibit infection in permissive lymphoid cells.

\section{PBMC co-culture assays}

At indicated times post inoculation, TERT-2 cells were COcultured in triplicate wells of 96-well plates with $2 \times 10^{5}$ activated PBMCs to estimate trans infection of cell-associated HIV. Co-culture was performed in $200 \mu \mathrm{L}$ of PBMC medium, which selectively supports viability of the PBMCs at the expense of the TERT-2 cells (require K-SFM supplement as above). After co-culture with HIV-infected TERT-2 cells, PBMC media were replaced $(100 \mu \mathrm{L})$ on day 4 , and supernatants were collected $(100 \mu \mathrm{L})$ on day 9 by centrifugation at $330 \times \mathrm{g}$ for $5 \mathrm{~min}$. The recovery of $\mathrm{p} 24 \mathrm{gag}$ was estimated in the PBMC supernatants with the Coulter HIV-1 p24gag Antigen Assay (Beckman Coulter) using the manufacturer's protocol. To estimate the release of HIV-1 from TERT- 2 cells, TERT- 2 culture supernatants $(50 \mu \mathrm{L})$ were collected and then inoculated into $2 \times 10^{5}$ activated PBMCs at selected times post inoculation. p24gag production was estimated in PBMCs cultures nine days later as described above.

\section{Identification of integrated HIV DNA, linear HIV DNA and two-LTR circles}

To identify integrated HIV DNA in TERT-2 cells, contaminating DNA from viral inocula (MOI 0.01) derived from propagating cells was carefully excluded. To partition contaminating DNA copies from TERT-2 cell integrated HIV DNA, TERT-2 cells $\left(9 \times 10^{4}\right.$ cells $)$ were grown in 6 -well plates and nuclei were isolated using the Nuclei EZ Prep Nuclei Isolation kit (Sigma). DNA was then extracted from the nuclei using the DNeasy kit (Qiagen) and quantified spectrophotometrically. PCR reactions contained 500 ng of TERT-2 DNA, primers and PCR conditions were as described (Table 2; $[25,40])$. Integrated HIV DNA was detected by nested PCR to increase sensitivity and fidelity
[25]. PCR products were identified on 3\% agarose gels stained with ethidium bromide.

\section{Analysis of multiply spliced, singly spliced, unspliced and U5-U3 HIV-I RNA}

Total RNA was collected from infected TERT-2 cells using Rneasy Plus Mini kit (Qiagen) and quantified spectrophotometrically. To detect viral-specific RNA using real time RT-PCR, $5 \mu \mathrm{g}$ of total RNA was reverse transcribed to cDNA using an Iscript ${ }^{\mathrm{TM}} \mathrm{cDNA}$ Synthesis Kit (BioRad). In separate PCRs, the cDNA product $(10 \mu \mathrm{l})$ was incubated with primers specific to multiply spliced HIV RNA, unspliced HIV RNA and U5-U3 RNA. Primer sequences and PCR conditions were as shown (Table 2; [25]). Glyceraldehyde-3-phosphate dehydrogenase (GAPDH) sequence was amplified as a control. PCR products were identified on 3\% agarose gels stained with ethidium bromide. The concentration and purity of RNA preparations was performed using the 2100 Bioanalyzer (Agilent). Total RNA (500 ng) was reverse transcribed to cDNA using the Superscript III First Strand Synthesis System. The cDNA was then diluted 1:5 with RNase/DNase free water and $1 \mu \mathrm{l}$ (5 ng) was used as a template in the Platinum SYBR Green qPCR SuperMix-UDG with ROX (Invitrogen). Real time PCR was performed on each sample in triplicate on an ABI7900 HT Real Time PCR machine (Applied Biosystems) and data was analyzed using SDS 2.1 software (Applied Biosystems). All genes were normalized to expression of human $\beta$-actin (SuperArray Bioscience). Relative expression was quantified using the delta-delta CT method [69].

\section{VLP infection}

To prepare for infection with virus-like particles (VLPs; pseudovirus), cells were grown overnight on gelatincoated cover slips in 24-well plates to approximately 50\% confluence. Cell monolayers were then incubated with VLPs at a MOI 10 for $6 \mathrm{~h}$ with $10 \mu \mathrm{g} / \mathrm{mL}$ Sequa-brene and then aspirated. At indicated times post inoculation, cells were fixed in $4 \%$ paraformaldehyde at room temperature for $10 \mathrm{~min}$, washed three times in $1 \mathrm{~mL}$ DPBS, and nuclei were stained with 4', 6-diamidino-2-phenylindole, dihydrochloride (DAPI; Molecular Probes). Cells were then washed three times in DPBS and the glass cover slips were mounted with Fluoromount G (Southern Biotech). EGFP expression was visualized with a fluorescence microscope (Eclipse E800, Nikon) under a $20 \times$ objective. Images were acquired using Spot Insight QE (Diagnostic Instrument, Inc.) and MetaMorph software (Molecular Devices). To characterize trans infection, TERT-2 cultures in 24-well tissue culture plates were incubated with VLPs at a MOI of 100 for $6 \mathrm{~h}$ in the presence of $10 \mu \mathrm{g} / \mathrm{mL}$ Sequa-brene. Supernatants were aspirated and TERT-2 cells were co-cultured with MOLT-4/CCR5 $\left(2 \times 10^{5}\right)$ cells. In some experiments, TERT- 2 cells were treated with trypsin or colchicine 
as above, or cooled to $4^{\circ} \mathrm{C}$ (or combinations of treatments) and transfer of VLPs was compared. At $48 \mathrm{~h}$ after co-culture, MOLT-4/CCR5 cells were collected by centrifugation at $330 \times \mathrm{g}$ for $5 \mathrm{~min}$, and washed three times in 1 mL DPBS with 2\% FBS. Cells were then resuspended in $200 \mu \mathrm{L}$ of $2 \%$ paraformaldehyde, and stored at $4{ }^{\circ} \mathrm{C}$. EGFP-positive cells were analyzed by use of a FACSVantage SE flow cytometer (BD Biosciences).

\section{Competing interests}

The authors declare that they have no competing interests.

\section{Authors' contributions}

AV contributed to the design of the study, evaluated the data, drafted the manuscript and performed all of the experimental procedures except as noted. AA carried out the SYBR real time PCR assays. KG prepared HIV stocks. CF performed flow cytometric analyses. RG and all authors contributed to the critical appraisal of the data. EJ contributed to the early design of the study. KR and $\mathrm{MH}$ conceived of the study, contributed to the design and coordination of the experiments, and critically reviewed and edited the manuscript. All authors read and approved the final manuscript.

\section{Acknowledgements}

These studies were supported by $\mathrm{NIH}$ grants-in-aid DE0I5503 (to $\mathrm{MCH}$ ), DEI5506 (KFR), HD4I36I (ENJ), DE7262I (ENJ), the Veterans Affairs Research Service, and the Mucosal and Vaccine Research Center. This manuscript has been submitted in partial fulfillment of the requirements for the $\mathrm{PhD}$ degree in oral biology by $\mathrm{AV}$.

\section{References}

I. Baron S, Poast J, Richardson CJ, Nguyen D, Cloyd M: Oral transmission of human immunodeficiency virus by infected seminal fluid and milk: a novel mechanism. J Infect Dis 2000, | 8 |:498-504.

2. Dunn DT, Newell ML, Ades AE, Peckham CS: Risk of human immunodeficiency virus type I transmission through breastfeeding. Lancet 1992, 340:585-588.

3. Syrjanen S: PL7 Oral viral infections that could be transmitted oro-genitally. Oral Dis 2006, I 2(Suppl I):2.

4. Schacker T, Collier AC, Hughes J, Shea T, Corey L: Clinical and epidemiologic features of primary HIV infection. Ann Intern Med 1996, I 25:257-264.

5. Lifson AR, O'Malley PM, Hessol NA, Buchbinder SP, Cannon L, Rutherford GW: HIV seroconversion in two homosexual men after receptive oral intercourse with ejaculation: implications for counseling concerning safe sexual practices. $\mathrm{Am} J$ Public Health 1990, 80(12): 1509-151 I.

6. Rodriguez-Inigo E, Jimenez E, Bartolome J, Ortiz-Movilla N, Bartolome Villar B, Jose Arrieta J, Manzarbeitia F, Carreno V: Detection of human immunodeficiency virus type I RNA by in situ hybridization in oral mucosa epithelial cells from anti-HIV-I positive patients. J Med Virol 2005, 77:17-22.

7. Qureshi MN, Barr CE, Hewlitt I, Boorstein R, Kong F, Bagasra O, Bobroski LE, Joshi B: Detection of HIV in oral mucosal cells. Oral Dis I 997, 3(SuppI I):S73-78.

8. Milush JM, Kosub D, Marthas M, Schmidt K, Scott F, Wozniakowski A, Brown C, Westmoreland S, Sodora DL: Rapid dissemination of SIV following oral inoculation. Aids 2004, I 8( ( 8):237|-2380.

9. Haase AT: Perils at mucosal front lines for HIV and SIV and their hosts. Nat Rev Immunol 2005, 5( I 0):783-792.

10. Ruprecht RM, Baba TW, Liska V, Ray NB, Martin LN, Murphey-Corb M, Rizvi TA, Bernacky BJ, Keeling ME, McClure HM, Andersen J: Oral transmission of primate lentiviruses. I Infect Dis 1999, 179(Suppl 3):S408-4I2.

II. Shaheen F, Collman RG: Co-receptor antagonists as HIV-I entry inhibitors. Curr Opin Infect Dis 2004, I7:7-16.

12. Fauci AS: The human immunodeficiency virus: infectivity and mechanisms of pathogenesis. Science 1988, 239:617-622.

13. Greene WC: The molecular biology of human immunodeficiency virus type I infection. N Engl J Med I99I, 324:308-3I7.

14. Walsh LJ, Ishii T, Savage NW, Gemmell E, Seymour G]: Immunohistologic analysis of epithelial cell populations in oral lichen planus. J Oral Pathol Med 1990, 19:177-181.

15. Fantini J, Hammache D, Delezay O, Yahi N, Andre-Barres C, RicoLattes I, Lattes A: Synthetic soluble analogs of galactosylceramide (GalCer) bind to the V3 domain of HIV-I gp I 20 and inhibit HIV-I-induced fusion and entry. J Biol Chem 1997, 272:7245-7252.

16. Bobardt MD, Salmon P, Wang L, Esko JD, Gabuzda D, Fiala M, Trono D, Schueren B Van der, David G, Gallay PA: Contribution of proteoglycans to human immunodeficiency virus type I brain invasion. J Virol 2004, 78:6567-6584.

17. Bobardt MD, Chatterji U, Selvarajah S, Schueren B Van der, David G, Kahn B, Gallay PA: Cell-free human immunodeficiency virus type I transcytosis through primary genital epithelial cells. J Virol 2007, 81:395-405.

18. Pang S, Yu D, An DS, Baldwin GC, Xie Y, Poon B, Chow YH, Park NH, Chen IS: Human immunodeficiency virus Env-independent infection of human CD4(-) cells. J Virol 2000, 74:10994-II000.

19. Bomsel M, Alfsen A: Entry of viruses through the epithelial barrier: pathogenic trickery. Nat Rev Mol Cell Biol 2003, 4:57-68.

20. Liu X, Zha J, Chen H, Nishitani J, Camargo P, Cole SW, Zack JA: Human immunodeficiency virus type $I$ infection and replication in normal human oral keratinocytes. J Virol 2003, 77:3470-3476.

21. Moore JS, Hall SD, Jackson S: Cell-associated HIV-I infection of salivary gland epithelial cell lines. Virology 2002, 297:89-97.

22. Moore JS, Rahemtulla F, Kent LW, Hall SD, Ikizler MR, Wright PF, Nguyen $\mathrm{HH}$, Jackson S: Oral epithelial cells are susceptible to cell-free and cell-associated HIV-I infection in vitro. Virology 2003, 3 1 3:343-353.

23. Chen J, Reeves L, Sanburn N, Croop J, Williams DA, Cornetta K: Packaging cell line DNA contamination of vector supernatants: implication for laboratory and clinical research. Virology 200I, 282:186-197.

24. Asin SN, Fanger MW, Wildt-Perinic D, Ware PL, Wira CR, Howell AL: Transmission of HIV-I by primary human uterine epithelial cells and stromal fibroblasts. J Infect Dis 2004, 190:236-245.

25. Brussel A, Sonigo P: Analysis of early human immunodeficiency virus type I DNA synthesis by use of a new sensitive assay for quantifying integrated provirus. J Virol 2003, 77:10119-10124.

26. Freed EO: HIV-I and the host cell: an intimate association. Trends Microbiol 2004, I 2:170-I77.

27. Gomez C, Hope TJ: The ins and outs of HIV replication. Cell Microbiol 2005, 7:621-626.

28. Rheinwald JG, Hahn WC, Ramsey MR, Wu JY, Guo Z, Tsao H, De Luca M, Catricala C, O'Toole KM: A two-stage, p I 6(INK4A)- and p53-dependent keratinocyte senescence mechanism that limits replicative potential independent of telomere status. Mol Cell Biol 2002, 22:5 I57-5I72.

29. Campo J, Perea MA, del Romero J, Cano J, Hernando V, Bascones A: Oral transmission of HIV, reality or fiction? An update. Oral Dis 2006, I 2:219-228.

30. Rupniak HT, Rowlatt C, Lane EB, Steele JG, Trejdosiewicz LK, Laskiewicz B, Povey S, Hill BT: Characteristics of four new human cell lines derived from squamous cell carcinomas of the head and neck. J Natl Cancer Inst 1985, 75(4):62I-635.

31. Eagle H: Propagation in a fluid medium of a human epidermoid carcinoma, strain KB. Proc Soc Exp Biol Med 1955, 89(3):362-364.

32. Andreadis D, Epivatianos A, Poulopoulos A, Nomikos A, Christidis K, Papazoglou G, Antoniades D, Barbatis C: Immunohistochemical detection of the expression of the cell adhesion molecules $E$ cadherin, desmoglein-2, beta4-integrin, ICAM-I and HCAM (CD44s) in Warthin's tumour of the parotid gland. Oral Oncol 2005, 4 I:799-805.

33. Folks TM, Clouse KA, Justement J, Rabson A, Duh E, Kehrl JH, Fauci AS: Tumor necrosis factor alpha induces expression of 
human immunodeficiency virus in a chronically infected $\mathrm{T}$ cell clone. Proc Natl Acad Sci USA 1989, 86:2365-2368.

34. Kage A, Shoolian E, Rokos K, Ozel M, Nuck R, Reutter W, Kottgen E, Pauli G: Epithelial uptake and transport of cell-free human immunodeficiency virus type I and gp I 20-coated microparticles. J Virol 1998, 72(5):423 I-4236.

35. Kotler DP: HIV infection and the gastrointestinal tract. Aids 2005, 19:107-117.

36. Milush JM, Stefano-Cole K, Schmidt K, Durudas A, Pandrea I, Sodora $D L:$ Mucosal innate immune response associated with a timely humoral immune response and slower disease progression after oral transmission of simian immunodeficiency virus to rhesus macaques. J Virol 2007, 81 :6175-6186.

37. Kumar RB, Maher DM, Herzberg MC, Southern PJ: Expression of HIV receptors, alternate receptors and co-receptors on tonsillar epithelium: implications for HIV binding and primary oral infection. Virol J 2006, 3:25.

38. Moutsopoulos NM, Nares S, Nikitakis N, Rangel Z, Wen J, Munson P, Sauk J, Wahl SM: Tonsil epithelial factors may influence oropharyngeal human immunodeficiency virus transmission. Am J Pathol 2007, 171:57I-579.

39. Decrion AZ, Dichamp I, Varin A, Herbein G: HIV and inflammation. Curr HIV Res 2005, 3:243-259.

40. Brussel A, Sonigo P: Evidence for gene expression by unintegrated human immunodeficiency virus type I DNA species. JVirol 2004, 78: I 1263-I I27I.

41. Goff SP: Retrovirus restriction factors. Mol Cell 2004, 16:849-859.

42. Aiken C: Pseudotyping human immunodeficiency virus type I (HIV-I) by the glycoprotein of vesicular stomatitis virus targets HIV-I entry to an endocytic pathway and suppresses both the requirement for Nef and the sensitivity to cyclosporin A. J Virol 1997, 7I(8):587I-5877.

43. Meng G, Wei X, Wu X, Sellers MT, Decker JM, Moldoveanu Z, Orenstein JM, Graham MF, Kappes JC, Mestecky J, Shaw GM, Smith PD: Primary intestinal epithelial cells selectively transfer R5 HIV. I to CCR5+ cells. Nat Med 2002, 8:150-I56.

44. Saphire AC, Bobardt MD, Zhang Z, David G, Gallay PA: Syndecans serve as attachment receptors for human immunodeficiency virus type I on macrophages. J Virol 200I, 75:9|87-9200.

45. Saidi H, Magri G, Nasreddine N, Requena M, Belec L: R5- and X4HIV-I use differentially the endometrial epithelial cells HEC. IA to ensure their own spread: implication for mechanisms of sexual transmission. Virology 2007, 358:55-68.

46. Patel M, Yanagishita M, Roderiquez G, Bou-Habib DC, Oravecz T, Hascall VC, Norcross MA: Cell-surface heparan sulfate proteoglycan mediates HIV-I infection of T-cell lines. AIDS Res Hum Retroviruses 1993, 9:167-174.

47. Vidricaire G, Gauthier S, Tremblay MJ: HIV-I infection of trophoblasts is independent of gp/20/CD4 Interactions but relies on heparan sulfate proteoglycans. J Infect Dis 2007 195:1461-1471.

48. Rahemtulla F, Moorer CM, Wille || Jr: Biosynthesis of proteoglycans by proliferating and differentiating normal human keratinocytes cultured in serum-free medium. J Cell Physiol 1989, 140:98-106.

49. Tonnaer EL, Hafmans TG, Van Kuppevelt TH, Sanders EA, Verweij PE, Curfs $\mathrm{J}$ : Involvement of glycosaminoglycans in the attachment of pneumococci to nasopharyngeal epithelial cells. Microbes Infect 2006, 8:316-322.

50. Larjava $H$, Hakkinen L, Rahemtulla F: A biochemical analysis of human periodontal tissue proteoglycans. Biochem J 1992, 284(Pt I):267-274.

51. Yura $\mathrm{Y}$, Iga $\mathrm{H}$, Kondo $\mathrm{Y}$, Harada $\mathrm{K}$, Tsujimoto $\mathrm{H}$, Yanagawa $\mathrm{T}$, Yoshida $H$, Sato M: Heparan sulfate as a mediator of herpes simplex virus binding to basement membrane. J Invest Dermatol 1992, 98:494-498.

52. Alfsen A, Yu H, Magerus-Chatinet A, Schmitt A, Bomsel M: HIV-Iinfected blood mononuclear cells form an integrin- and agrin-dependent viral synapse to induce efficient HIV-I transcytosis across epithelial cell monolayer. Mol Biol Cell 2005, 16:4267-4279.

53. Guibinga GH, Miyanohara A, Esko JD, Friedmann T: Cell surface heparan sulfate is a receptor for attachment of envelope protein-free retrovirus-like particles and VSV-G pseudo- typed MLV-derived retrovirus vectors to target cells. Mol Ther 2002, 5:538-546.

54. Bugatti A, Urbinati C, Ravelli C, De Clercq E, Liekens S, Rusnati M: Heparin-mimicking sulfonic acid polymers as multitarget inhibitors of HIV-I Tat and gp I 20 proteins. Antimicrob Agents Chemother 2007.

55. Wiley RD, Gummuluru S: Immature dendritic cell-derived exosomes can mediate HIV-I trans infection. Proc Natl Acad Sci USA 2006, 103:738-743.

56. Daecke J, Fackler OT, Dittmar MT, Krausslich HG: Involvement of clathrin-mediated endocytosis in human immunodeficiency virus type I entry. IVirol 2005, 79:।58|-1594.

57. de Witte L, Nabatov A, Pion M, Fluitsma D, de Jong MA, de Gruijl T, Piguet $\mathrm{V}$, van Kooyk Y, Geijtenbeek TB: Langerin is a natural barrier to HIV-I transmission by Langerhans cells. Nat Med 2007, |3:367-37|

58. Fahrbach KM, Barry SM, Ayehunie S, Lamore S, Klausner M, Hope T]: Activated CD34-derived Langerhans cells mediate transinfection with human immunodeficiency virus. J Virol 2007, 81:6858-6868.

59. Giacaman RANA, Ross KF, Herzberg MC: Porphyromonas gingivalis selectively up-regulates the HIV-I coreceptor CCR5 in oral keratinocytes. J Immunol 2007, 179:2542-2550.

60. Giacaman RA, Asrani AC, Gebhard KH, Dietrich EA, Vacharaksa A Ross KF, Herzberg MC: Porphyromonas gingivalis induces CCR5dependent transfer of infectious HIV-I from oral keratinocytes to permissive cells. Retrovirology 2008, 5:29.

6I. Moore BE, Flaitz CM, Coppenhaver DH, Nichols M, Kalmaz GD, Bessman JD, Cloyd MW, Lynch DP, Prabhakar BS, Baron S: HIV recovery from saliva before and after dental treatment: inhibitors may have critical role in viral inactivation. J $\mathrm{Am}$ Dent Assoc 1993, I 24(1 0):67-74.

62. Kazmi SH, Naglik JR, Sweet SP, Evans RW, O'Shea S, Banatvala JE, Challacombe SJ: Comparison of human immunodeficiency virus type I-specific inhibitory activities in saliva and other human mucosal fluids. Clin Vaccine Immunol 2006, I 3: I I I- I I I8.

63. Skott $P$, Lucht $E$, Ehnlund $M$, Bjorling $E$ : Inhibitory function of secretory leukocyte proteinase inhibitor (SLPI) in human saliva is HIV-I specific and varies with virus tropism. Oral Dis 2002, 8: 160-167.

64. Habte HH, Mall AS, de Beer C, Lotz ZE, Kahn D: The role of crude human saliva and purified salivary MUC5B and MUC7 mucins in the inhibition of Human Immunodeficiency Virus type $I$ in an inhibition assay. Virol J 2006, 3:99.

65. Oda D, Watson E: Human oral epithelial cell culture I. Improved conditions for reproducible culture in serum-free medium. In Vitro Cell Dev Biol 1990, 26:589-595.

66. Ulmer AJ, Scholz W, Ernst M, Brandt E, Flad HD: Isolation and subfractionation of human peripheral blood mononuclear cells (PBMC) by density gradient centrifugation on Percoll. Immunobiology 1984, 166:238-250.

67. Naldini L, Blomer U, Gallay P, Ory D, Mulligan R, Gage FH, Verma IM, Trono $D$ : In vivo gene delivery and stable transduction of nondividing cells by a lentiviral vector. Science 1996, 272:263-267.

68. Matumoto M: A note on some points of calculation method of LD50 by Reed and Muench. Jpn J Exp Med 1949, 20:175-179.

69. Livak KJ, Schmittgen TD: Analysis of relative gene expression data using real-time quantitative PCR and the 2(-Delta Delta C(T)) Method. Methods 200I, 25:402-408.

70. Vives RR, Imberty A, Sattentau QJ, Lortat-Jacob H: Heparan sulfate targets the HIV-I envelope glycoprotein gp I 20 coreceptor binding site. J Biol Chem 2005, 280:21353-2I357.

7I. Augustin LA, Fantini J, Mootoo DR: C-Glycoside analogues of beta-galactosylceramide with a simple ceramide substitute: synthesis and binding to HIV-I gpI 20. Bioorg Med Chem 2006, 14:1182-1188.

72. Sattentau QJ, Dalgleish AG, Weiss RA, Beverley PC: Epitopes of the CD4 antigen and HIV infection. Science 1986, 234: I I 20- I I 23.

73. Deng H, Liu R, Ellmeier W, Choe S, Unutmaz D, Burkhart M, Di Marzio P, Marmon S, Sutton RE, Hill CM, Davis CB, Peiper SC, Schall TJ, Littman DR, Landau NR: Identification of a major co-receptor for primary isolates of HIV-I. Nature 1996, 381:66I-666.

74. Asin SN, Wildt-Perinic D, Mason SI, Howell AL, Wira CR, Fanger $\mathrm{MW}$ : Human immunodeficiency virus type $I$ infection of human uterine epithelial cells: viral shedding and cell contact-mediated infectivity. J Infect Dis 2003, 187:1522-1533. 